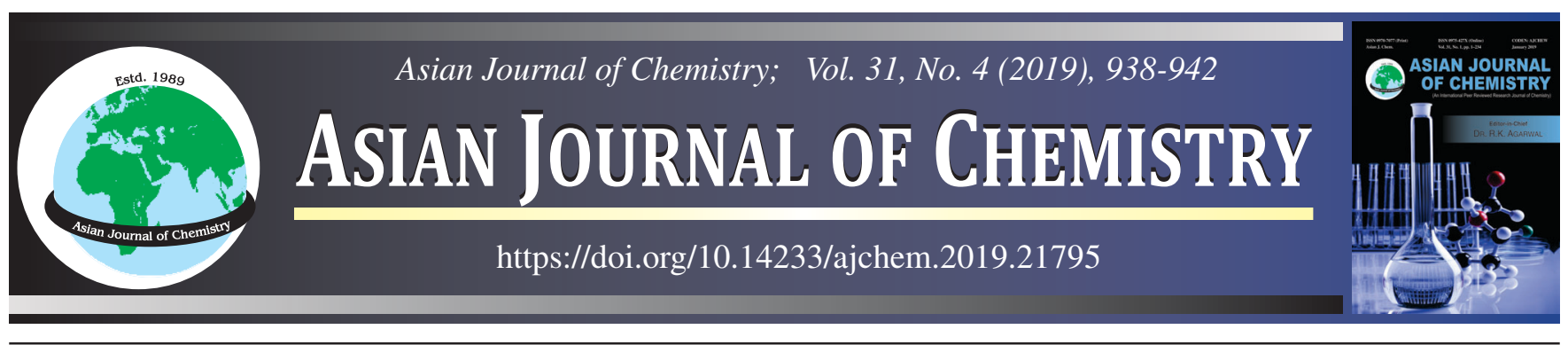

\title{
Synthesis, Characterization and Antimicrobial Screening of Novel Hydrazide Ligand \& It's Transition Metal Complexes
}

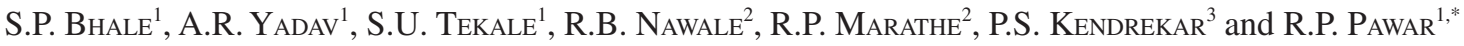

${ }^{1}$ Department of Chemistry, Deogiri College, Aurangabad-431005, India

${ }^{2}$ Department of Chemistry, Government College of Pharmacy, Aurangabad-431005, India

${ }^{3}$ Department of Health Sciences, Central University of Technology, Bloemfontein 9033, Free State, South Africa

*Corresponding author: E-mail: rppawar@yahoo.com

Received: 3 November 2018;

Accepted: 16 January 2019;

Published online: 27 February 2019;

AJC-19309

Different transition metal complexes were synthesized from novel 3-bromo-2-[1-(4-hydroxy-6-methyl-2-oxo-2H-pyran-3yl)ethylidene]hydrazide ligand $\left(\mathrm{H}_{2} \mathrm{~L}\right)$ and characterized by spectral techniques. The synthesized ligand was found to act mono as well as di deprotonated $(\mathrm{OH}, \mathrm{NH})$ manner and stoichiometry of the ligand to metal ions was confirmed to be 1:1 in case of complex using metal chloride salts, whereas 1:2 in case of metal(II) complexes using metal acetate(II) salt. Structures of metal complexes were confirmed by IR, ${ }^{1} \mathrm{H}$ NMR, TGA, XRD, elemental analysis and UV technique which revealed that $\mathrm{Mn}(\mathrm{II}), \mathrm{Co}(\mathrm{II}), \mathrm{Ni}(\mathrm{II}), \mathrm{Cu}$ (II) complexes were octahedral geometry and those of $\mathrm{Cu}$ (II), $\mathrm{Zn}$ (II) showed square planner and tetrahedral geometry around metal ion respectively. Furthermore $\mathrm{H}_{2} \mathrm{~L}$ and its metal complexes were screened for antimicrobial activity which showed that ligand enhanced its biological activity after coordination with metal ions. In particular, $\mathrm{Cd}(\mathrm{II})$ and $\mathrm{Mn}$ (II) complexes exhibited excellent antifungal activity.

Keywords: ONO donor ligand, Transition metal complexes, Antimicrobial.

L

\section{INTRODUCTION}

Coordination chemistry of substituted hydrazone ligands is well known since past few decades due to their structural flexibility, chelating abilities, diverse bonding modes towards transition metal ions and numerous biological applications [1-4]. The presence of azomethine group in Schiff's bases is known for antifungal [5], antibacterial [6], antitubercular [7], antitumor [8] and anticancer [9] properties. Oxygen containing heterocyclic compound like dehydroacetic acid (DHA) is well known chelating agent with excellent insecticidal and herbicidal activities $[10,11]$. The copper complex of hydrazone based ligand prepared by the condensation of dehydroacetic acid with 1,2-diaminopropane displays electro catalytic behaviour towards electro reduction of aryl and alkyl halides [12]. Transition metal complexes of hydrazone are reported for excellent catalytic activities in different chemical reactions such as polymerization of ethylene [13], epoxidation of olefins [14,15] and transamination of carboxamides with amines [16].
In continuation of our present work in the synthesis and biological evaluation of metal complexes [17-19]; in the present article we report synthesis of dehydroacetic acid (DHA) based tridentate 3-bromo-2-[1-(4-hydroxy-6-methyl-2-oxo- $2 \mathrm{H}$ pyran-3yl)ethylidene]hydrazide $\left(\mathrm{H}_{2} \mathrm{~L}\right)$ ligand and its transition metal complexes. $\mathrm{H}_{2} \mathrm{~L}$ was synthesized by the condensation of dehydroacetic acid (DHA) and 3-bromobenzhydrazide. Synthesized ligand was characterized by different spectroscopic techniques. The synthesized ligand and its complexes were furthermore screened for antimicrobial activity.

\section{EXPERIMENTAL}

All the purchased chemicals were analytical grade and used without further purification. Solvents were purified and dried according to literature method [20]. Dehydroacetic acid (DHA) and ethyl-3-bromo benzoate were Alfa Aesar and Spectrochem made respectively. Metal salts were SD Fine made \& used without further purification.

This is an open access journal, and articles are distributed under the terms of the Creative Commons Attribution-NonCommercial-ShareAlike 4.0 (CC BY-NC-SA 4.0) International License which allows readers to freely read, download, copy, distribute, print, search, or link to the full texts of its articles and to use them for any other lawful non-commercial purpose as long as the original source is duly acknowledged. 
Synthesis of 3-bromobenzhydrazide (3a): A mixture of ethyl-3-bromobenzoate (1) $(2 \mathrm{mmol})$ and hydrazine hydrate (2) $(80 \%)(3 \mathrm{mmol})$ was refluxed for $7 \mathrm{~h}$. The progress of reaction was monitored by TLC using $20 \%$ EtOAc: $n$-hexane. After completion of reaction; the reaction mixture was cooled, the precipitated solid was filtered off, recrystallized from ethanol and confirmed by ${ }^{1} \mathrm{H}$ NMR as the pure hydrazide (3a) (SchemeI). Yield $=80 \%$, Colour-White, solid, m.p. $158{ }^{\circ} \mathrm{C} ;{ }^{1} \mathrm{H}$ NMR (200 MHz, DMSO- $d_{6}$ ) ppm 4.54 (br., s., $2 \mathrm{H}, \mathrm{NH}_{2}$ ), 7.37 - 7.47 $(\mathrm{dd}, J=8.5,8 \mathrm{~Hz}, 1 \mathrm{H}), 7.67-7.86$ (m, $2 \mathrm{H}), 7.98$ (dd, $J=1.83$, $1.71 \mathrm{~Hz}, 1 \mathrm{H}$ ), 9.89 (br., s., $1 \mathrm{H}, \mathrm{NH}$ ).

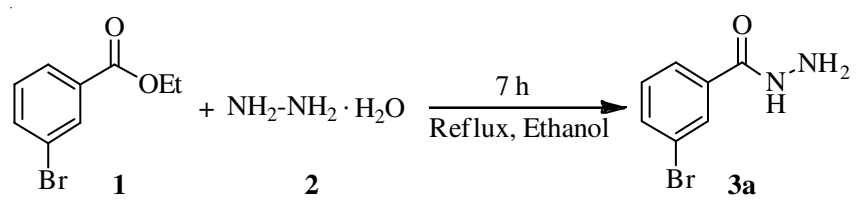

Scheme-I: Synthesis of 3-bromobenzhydrazide

Synthesis of 3-bromo-2-[1-(4-hydroxy-6-methyl-2-oxo$2 \mathrm{H}$-pyran-3-yl)ethylidene]-hydrazide $\left(\mathrm{H}_{2} \mathrm{~L}\right)(5 \mathrm{a})$ : 3 -Bromobenzhydrazide (3a) $(1 \mathrm{~g}$; $0.004 \mathrm{~mol})$ was added to a solution of dehydroacetic acid (DHA) (4) (0.785 g; $0.004 \mathrm{~mol})$ in ethanol $(15 \mathrm{~mL})$ and the mixture was refluxed for $1.5 \mathrm{~h}$. The pale yellow precipitate obtained was filtered off; washed with ethanol and recrystallized from ethanol as the pure ligand $\mathrm{H}_{2}$ L.Yield- $85 \%$, Colour-White, m.p. $278^{\circ} \mathrm{C}$ (Scheme-II).

Spectral data of ligand $\left(\mathbf{H}_{2} \mathrm{~L}\right)$ : IR $\left(\mathrm{KBr}, v_{\max }, \mathrm{cm}^{-1}\right)$ : $3134.33(\mathrm{NH}), 1662.64$ (pyranone $\mathrm{C}=\mathrm{O}), 1600(\mathrm{C}=\mathrm{O}) ;{ }^{1} \mathrm{H}$ NMR (500 MHz, DMSO- $\left.d_{6}\right) \delta$ ppm $2.13\left(\mathrm{~s}, 3 \mathrm{H}, \mathrm{CH}_{3}\right), 2.63$ (s, $\left.3 \mathrm{H}, \mathrm{N}=\mathrm{C}-\mathrm{CH}_{3}\right), 5.89(\mathrm{~s}, 1 \mathrm{H}$, ring proton), 7.50-7.54 (dd, $J=$

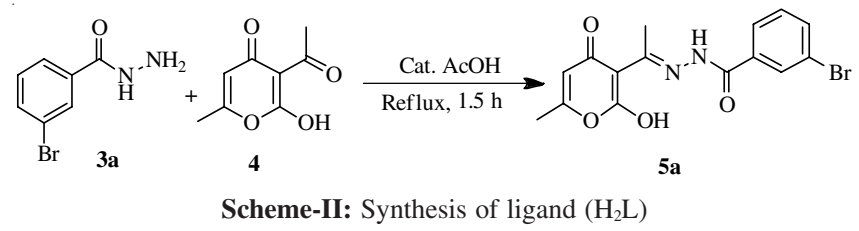

$10,7.5 \mathrm{~Hz}, 1 \mathrm{H}, \mathrm{Ar}-\mathrm{H}), 7.86-7.92$ (m, 2H, Ar-H), 8.08-8.09 (dd, $J=1.8,1.5 \mathrm{~Hz}, 1 \mathrm{H}, \mathrm{Ar}-\mathrm{H}$ ), 11.73 (br., s, $1 \mathrm{H}, \mathrm{CONH}$ ), 16.00 (br., s, $1 \mathrm{H}$, enolic $\mathrm{OH}$ of DHA); ${ }^{13} \mathrm{C}$ NMR (500 MHz, DMSO$\left.d_{6}\right): \delta$ ppm-17.07 (s, azomethine- $\left.\mathrm{CH}_{3}\right), 19.30$ (s, DHA- $\mathrm{CH}_{3}$ ), 94.93 (quat, DHA), 105.91 (s, DHA), 121.80 (quat, Ar), 127.08 (s, Ar), 130.45 (s, Ar), 133.68 (quat, Ar), 135.21 (s, Ar) 162.32 (quat, azomethine), 163.34 (quat, $\mathrm{C}=\mathrm{O}$ ), 171.28 (quat, $\mathrm{DHA}$ ), 182.00 (quat, 2C, DHA enolic); LC-MS: $m / z(\%) 365.0(\mathrm{M}+\mathrm{H})$, $367(\mathrm{M}+2)$.

General procedure for the synthesis of metal complexes (6a-g): Methanolic solution of corresponding metal salt (chloride or acetate) was added to the methanolic solution of ligand $\left(\mathrm{H}_{2} \mathrm{~L}\right)$. A slightly basic $\mathrm{pH}$ of the mixture for 1:1 ratio of metal to ligand was maintained by adding alcoholic ammonia and the contents were refluxed for $6 \mathrm{~h}$. The reaction was confirmed to be complete after the disappearance of starting materials on TLC. The products were filtered off, washed with hot methanol thrice (Scheme-III). The physical and analytical data of synthe-sized compounds is mentioned in Table-1.

\section{RESULTS AND DISCUSSION}

Infrared spectra: The band at $3514 \mathrm{~cm}^{-1}$ in infrared spectrum of free ligand for $-\mathrm{OH}$ stretching of pyranone ring<smiles></smiles>

6e, f . $\mathrm{M}=\mathrm{Cu}$ (II), $\mathrm{Zn}$ (II).

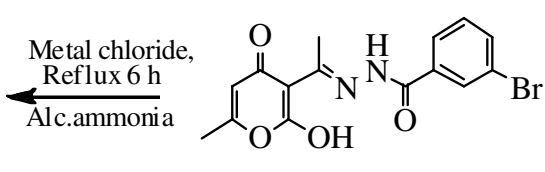

5a

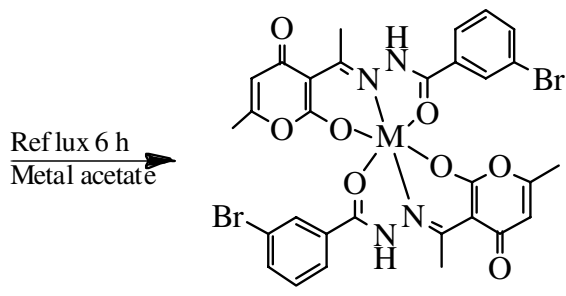

6a, b, c, d, g. $\mathrm{M}=\mathrm{Mn}$ (II), $\mathrm{Co}$ (II), $\mathrm{Ni}$ (II), $\mathrm{Cu}$ (II), Cd (II).

Scheme-III: Synthesis of metal complexes $(\mathbf{6 a - g})$

TABLE-1

PHYSICAL AND ANALYTICAL DATA OF THE SYNTHESIZED COMPOUNDS

\begin{tabular}{|c|c|c|c|c|c|c|c|c|}
\hline \multirow{2}{*}{ Compd. No. } & \multirow{2}{*}{ Compound } & \multirow{2}{*}{ m.f. (F.W.) } & \multirow{2}{*}{ m.p. $\left({ }^{\circ} \mathrm{C}\right)$} & \multirow{2}{*}{ Colour } & \multicolumn{4}{|c|}{ Elemental analysis (\%): Found (Calcd.) } \\
\hline & & & & & $\mathrm{C}$ & $\mathrm{H}$ & $\mathrm{N}$ & M \\
\hline $5 \mathbf{a}$ & Ligand $\left(\mathrm{H}_{2} \mathrm{~L}\right)$ & $\begin{array}{c}\mathrm{C}_{15} \mathrm{H}_{13} \mathrm{~N}_{2} \mathrm{O}_{4} \mathrm{Br} \\
(364.00)\end{array}$ & 278 & White & $\begin{array}{c}49.20 \\
(49.33)\end{array}$ & $\begin{array}{c}3.63 \\
(3.59)\end{array}$ & $\begin{array}{c}7.77 \\
(7.67)\end{array}$ & - \\
\hline $6 \mathbf{a}$ & {$\left[\mathrm{Mn}(\mathrm{HL})_{2}\right]$} & $\begin{array}{c}\mathrm{C}_{30} \mathrm{H}_{24} \mathrm{~N}_{4} \mathrm{O}_{8} \mathrm{Br}_{2} \mathrm{Mn} \\
(780.93)\end{array}$ & $>300$ & Light yellow & $\begin{array}{c}46.12 \\
(46.00)\end{array}$ & $\begin{array}{c}3.04 \\
(3.09)\end{array}$ & $\begin{array}{c}7.26 \\
(7.15)\end{array}$ & $\begin{array}{c}7.08 \\
(7.01)\end{array}$ \\
\hline $\mathbf{6 b}$ & {$\left[\mathrm{Co}(\mathrm{HL})_{2}\right]$} & $\begin{array}{c}\mathrm{C}_{30} \mathrm{H}_{24} \mathrm{~N}_{4} \mathrm{O}_{8} \mathrm{Br}_{2} \mathrm{Co} \\
(385.00)\end{array}$ & $>300$ & Brown & $\begin{array}{c}45.84 \\
(45.77)\end{array}$ & $\begin{array}{c}3.30 \\
(3.07)\end{array}$ & $\begin{array}{c}7.03 \\
(7.12)\end{array}$ & $\begin{array}{c}7.36 \\
(7.49)\end{array}$ \\
\hline 6c & {$\left[\mathrm{Ni}(\mathrm{HL})_{2}\right]$} & $\begin{array}{c}\mathrm{C}_{30} \mathrm{H}_{24} \mathrm{~N}_{4} \mathrm{O}_{8} \mathrm{Br}_{2} \mathrm{Ni} \\
(384.00)\end{array}$ & $>300$ & Orange & $\begin{array}{c}45.84 \\
(45.78)\end{array}$ & $\begin{array}{c}3.13 \\
(3.07)\end{array}$ & $\begin{array}{c}7.26 \\
(7.12)\end{array}$ & $\begin{array}{c}7.35 \\
(7.46)\end{array}$ \\
\hline 6d & {$\left[\mathrm{Cu}(\mathrm{HL})_{2}\right]$} & $\begin{array}{c}\mathrm{C}_{30} \mathrm{H}_{24} \mathrm{~N}_{4} \mathrm{O}_{8} \mathrm{Br}_{2} \mathrm{Cu} \\
(788.92)\end{array}$ & $>300$ & Greenish & $\begin{array}{c}45.46 \\
(45.50)\end{array}$ & $\begin{array}{c}3.23 \\
(3.05)\end{array}$ & $\begin{array}{c}7.15 \\
(7.08)\end{array}$ & $\begin{array}{c}8.01 \\
(8.02)\end{array}$ \\
\hline $6 e$ & {$\left[\mathrm{Cu}(\mathrm{L})\left(\mathrm{H}_{2} \mathrm{O}\right)\right]$} & $\begin{array}{c}\mathrm{C}_{15} \mathrm{H}_{13} \mathrm{~N}_{2} \mathrm{O}_{5} \mathrm{BrCu} \\
(442.93)\end{array}$ & $>300$ & Blue & $\begin{array}{c}40.62 \\
(40.51)\end{array}$ & $\begin{array}{c}2.77 \\
(2.95)\end{array}$ & $\begin{array}{c}6.28 \\
(6.30)\end{array}$ & $\begin{array}{c}14.35 \\
(14.29)\end{array}$ \\
\hline $6 \mathbf{f}$ & {$\left[\mathrm{Zn}(\mathrm{L})\left(\mathrm{H}_{2} \mathrm{O}\right)\right]$} & $\begin{array}{c}\mathrm{C}_{15} \mathrm{H}_{13} \mathrm{~N}_{2} \mathrm{O}_{5} \mathrm{BrZn} \\
(443.92)\end{array}$ & $>300$ & Yellow & $\begin{array}{c}40.53 \\
(40.34)\end{array}$ & $\begin{array}{c}2.82 \\
(2.93)\end{array}$ & $\begin{array}{c}6.36 \\
(6.27)\end{array}$ & $\begin{array}{c}14.60 \\
(14.64)\end{array}$ \\
\hline $6 \mathrm{~g}$ & {$\left[\mathrm{Cd}(\mathrm{HL})_{2}\right]$} & $\begin{array}{c}\mathrm{C}_{30} \mathrm{H}_{24} \mathrm{~N}_{4} \mathrm{O}_{8} \mathrm{Br}_{2} \mathrm{Cd} \\
(839.89)\end{array}$ & $>300$ & Cream yellow & $\begin{array}{c}42.95 \\
(42.86) \\
\end{array}$ & $\begin{array}{r}2.79 \\
(2.88) \\
\end{array}$ & $\begin{array}{c}6.78 \\
(6.66) \\
\end{array}$ & $\begin{array}{c}13.25 \\
(13.37) \\
\end{array}$ \\
\hline
\end{tabular}


disappearing in all metal complexes clearly indicates the participation of pyranone oxygen in coordination with the metal ions by deprotonation [21]. The strong band for azomethine group at $1595 \mathrm{~cm}^{-1}$ in ligand was shifted to lower side in the IR spectrum of all metal complexes, indicating the coordination of azomethine nitrogen to metal ion. In free ligand band at $1662 \mathrm{~cm}^{-1}$ arises due to $\mathrm{C}=\mathrm{O}$ stretch of pyranone ring in all metal complexes which indicates its non-participation in coordination. Spectral data suggests that the ligand has coordinated through azomethine nitrogen, amide carbonyl oxygen and oxygen of pyranone ring by deprotonation in all metal complexes, but in 2:1 ratio of ligand to metal the amide $\mathrm{C}=\mathrm{O}$ coordinated without deprotonation.

The band for O-H stretch at $3514 \mathrm{~cm}^{-1}$ in free ligand disappears in $\left[\mathrm{Zn}(\mathrm{L})\left(\mathrm{H}_{2} \mathrm{O}\right)\right]$. An additional band appearing at 3522 $\mathrm{cm}^{-1}$ is due to coordination of water molecule to metal ion. Azomethine nitrogen band at $1595 \mathrm{~cm}^{-1}$ was shifted to lower region at $1573 \mathrm{~cm}^{-1}$ indicating the coordination of azomethine nitrogen to metal ion. The absence of band at $3134 \mathrm{~cm}^{-1}$ for amide N-H stretch in complex indicates the coordination of amide oxygen through enolate by deprotonation. Thus, from IR data the ligand acts as monobasic for $\left[\mathrm{Mn}(\mathrm{HL})_{2}\right],\left[\mathrm{Co}(\mathrm{HL})_{2}\right]$, $\left[\mathrm{Cu}(\mathrm{HL})_{2}\right],\left[\mathrm{Ni}(\mathrm{HL})_{2}\right]$ complexes and dibasic for $\left[\mathrm{Zn}(\mathrm{L})\left(\mathrm{H}_{2} \mathrm{O}\right)\right]$, $\left[\mathrm{Cu}(\mathrm{L})\left(\mathrm{H}_{2} \mathrm{O}\right)\right]$ complexes.

NMR analysis: Two signals observed at 16.00 and 11.73 $\delta$ ppm correspond to enolic $\mathrm{OH}$ and amide $\mathrm{NH}$ respectively in the ${ }^{1} \mathrm{H}$ NMR spectrum of the free ligand. These signals were disappeared in ${ }^{1} \mathrm{H}$ NMR spectrum of $\left.\left[\mathrm{Zn}(\mathrm{L}) \mathrm{H}_{2} \mathrm{O}\right)\right]$ complex indicating the coordination of these two sites via deprotonation. The aromatic protons in the range of 7.902-8.092 $\delta$ ppm resonating as multiplet in ${ }^{1} \mathrm{H}$ NMR spectrum of non-coordinated ligand have shifted slightly to downfield in the range 8.05$8.16 \delta \mathrm{ppm}$ of metal complex. Two $\mathrm{CH}_{3}$ protons were observed as singlets at 2.136 and $2.632 \delta \mathrm{ppm}$ in free ligand have moved to 2.06 and $2.55 \delta \mathrm{ppm}$ respectively after formation of the complex [22].

In ${ }^{13} \mathrm{C}$ NMR spectrum of free ligand signals observed at 182.00 and $17.07 \mathrm{ppm}$ corresponds to $2 \mathrm{C}$ (quat.) (DHA) and azomethine(s) $\mathrm{CH}_{3}$ respectively were shifted to 178.86 and 19.19 $\delta \mathrm{ppm}$ in the spectrum of $\left.\left[\mathrm{Zn}(\mathrm{L}) \mathrm{H}_{2} \mathrm{O}\right)\right]$ complex, indicating the coordination of ligand-OH via deprotonation. The azomethine carbon has moved to downfield in the spectrum of complex indicating the participation of azomethine nitrogen in complexation with metal ion. The two aromatic quartets for carbons observed at 121.80 and $133.68 \delta \mathrm{ppm}$ in the ligand were shifted to downfield at 121.44 and $132.21 \delta \mathrm{ppm}$, which also confirms the coordination of amide $\mathrm{NH}$ via deprotonation.

Thermal analysis: Thermal study of metal complexes gives an idea about the presence or absence of lattice or coordinated held solvent molecules and is useful to confirm their composition and thermal stability. The thermal analysis was performed under nitrogen atmosphere in the temperature range of $25-800{ }^{\circ} \mathrm{C}$ at a heating rate of $10{ }^{\circ} \mathrm{C}$ per min.

The thermogram of $\left.\left[\mathrm{Zn}(\mathrm{L}) \mathrm{H}_{2} \mathrm{O}\right)\right]$ gives two peaks as shown in Fig. 1. At about $260^{\circ} \mathrm{C}$, most of the organic material along with water has been evaporated. Whereas at $450{ }^{\circ} \mathrm{C}$, the metal was converted to its oxide which is not decomposed upon heating upto $600{ }^{\circ} \mathrm{C}$.

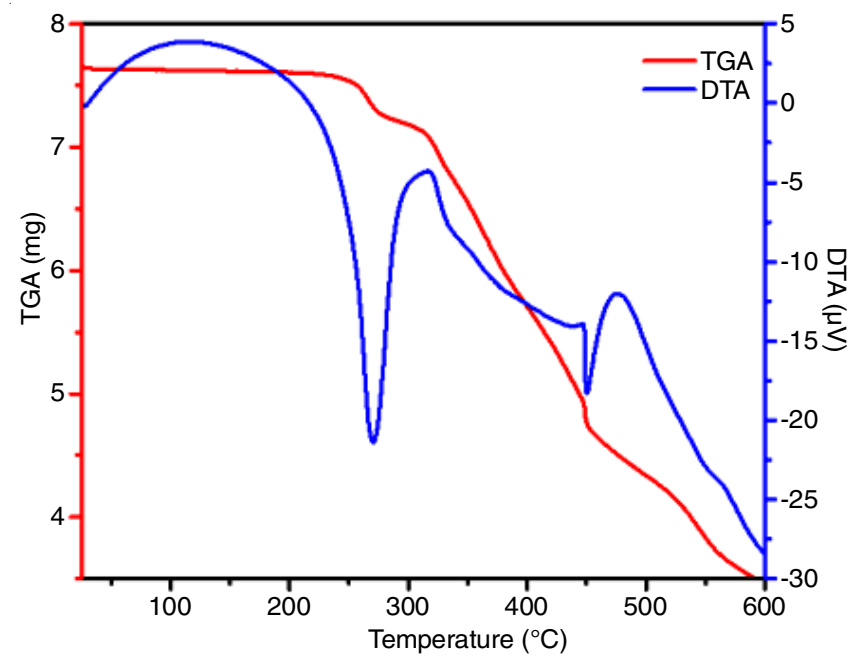

Fig. 1. TGA-DTA analysis of $\left[\mathrm{Zn}(\mathrm{L})\left(\mathrm{H}_{2} \mathrm{O}\right)\right]$

Electronic spectra: Electronic spectra of the synthesized transition metal complexes were recorded in DMSO solvent at room temperature. The complexes exhibited two bands in the range $349-375 \mathrm{~nm}$ which were assigned for charge transfer spectra observed after complex formation [23]. This indicated the coordination of azomethine nitrogen to metal ions and another band in the range of $280-290 \mathrm{~nm}$ corresponding to the $\pi \rightarrow \pi^{*}$ transition (Fig. 2).

Antimicrobial study: Antimicrobial activity of the synthesized compounds was evaluated against one bacterial Streptococcus aureus and two fungal species Aspergillums niger and Alternaria alternata using petri plate method at $250 \mathrm{ppm}$ concentration in DMSO solvent and compared with the standard antibiotics - streptomycin and carbendazim respectively. The petri plate (stains) containing $30 \mathrm{~mL}$ nutrient agar and potato dextrose agar (PDA) medium for bacteria and fungi were incubated for $20-24 \mathrm{~h}$ and $24-48 \mathrm{~h}$ respectively at $37{ }^{\circ} \mathrm{C}$ and the zones of inhibition were measured in terms of $\mathrm{mm}$. The results were compared with the standard antibiotics. The metal complexes showed more inhibitory effects than the non-coordinated ligand against used species under identical condition.

From Table-2, antibacterial activity of ligand and the synthesized metal complexes was found to be less against Streptococcus aureus as compared with the standard drug streptomycin. However Cd(II) and Mn(II) complexes exhibited excellent activity against Alternaria alternata than the standard drug carbenzadim. The remaining compounds showed lesser activity. On the other hand; Cd (II) complex exhibited excellent activity against Aspergillums niger even more than the standard drug carbendazim.

\section{Conclusion}

In conclusion, a new 3-bromo-2-[1-(4-hydroxy-6-methyl2-oxo-2H-pyran-3-yl)ethylidene] hydrazide ligand and its transition metal complexes were synthesized and characterized. Antimicrobial activity of the synthesized compounds revealed that the $\mathrm{Cd}(\mathrm{II})$ complex shows excellent activity against fungal species and $\mathrm{Mn}$ (II) complex shows moderate to good activity against A. niger and Alternaria alternata, respectively. However, antibacterial activity of all the screened compounds was found to be less in comparison with the standard. 

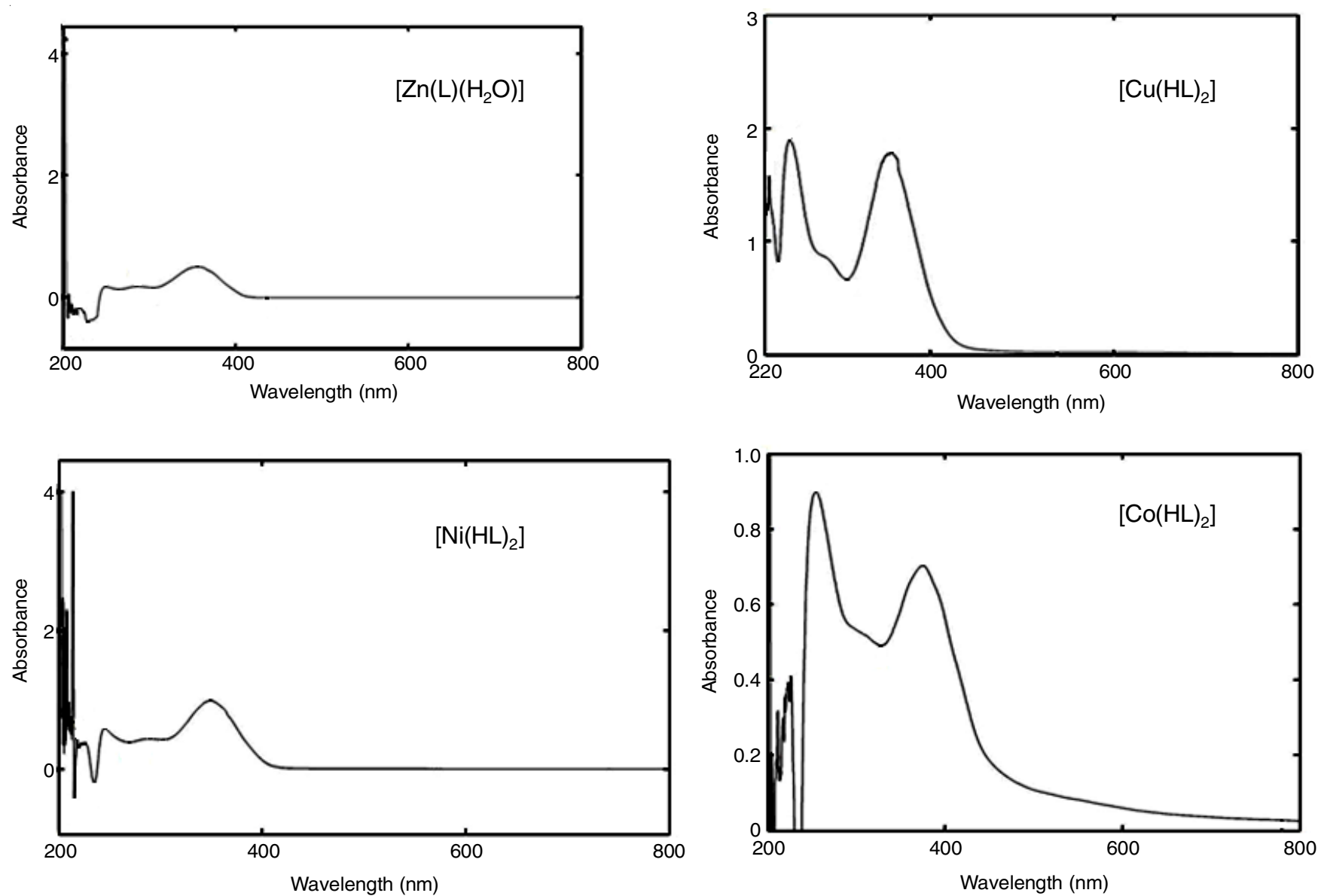

Fig. 2. Electronic spectra of the synthesized metal complexes

\begin{tabular}{|c|c|c|c|c|}
\hline \multicolumn{5}{|c|}{$\begin{array}{c}\text { TABLE-2 } \\
\text { ANTIMICROBIAL ACTIVITY OF THE SYNTHESIZED } \\
\text { LIGANDS AND ITS TRANSITION METAL COMPLEXES }\end{array}$} \\
\hline \multirow{3}{*}{$\begin{array}{c}\text { Compd. } \\
\text { No. }\end{array}$} & \multirow{3}{*}{ Compound } & \multicolumn{3}{|c|}{ Mean zone of inhibition diameter in $\mathrm{mm}$} \\
\hline & & \multicolumn{2}{|c|}{ Antifungal screening } & $\begin{array}{l}\text { Antibacterial } \\
\text { screening }\end{array}$ \\
\hline & & A. niger & A. alternata & S. aureus \\
\hline $5 \mathbf{5 a}$ & Ligand $\left(\mathrm{H}_{2} \mathrm{~L}\right)$ & 15 & 5 & 15 \\
\hline $6 \mathbf{a}$ & {$\left[\mathrm{Mn}(\mathrm{HL})_{2}\right]$} & 22 & 35 & 15 \\
\hline 6b & {$\left[\mathrm{Co}(\mathrm{HL})_{2}\right]$} & 20 & 27 & 17 \\
\hline $6 c$ & {$\left[\mathrm{Ni}(\mathrm{HL})_{2}\right]$} & 15 & 5 & 11 \\
\hline 6d & {$\left[\mathrm{Cu}(\mathrm{HL})_{2}\right]$} & 5 & 20 & 12 \\
\hline $6 e$ & {$\left[\mathrm{Cu}(\mathrm{L})\left(\mathrm{H}_{2} \mathrm{O}\right)\right]$} & 20 & 35 & 12 \\
\hline 6f & {$\left[\mathrm{Zn}(\mathrm{L})\left(\mathrm{H}_{2} \mathrm{O}\right)\right]$} & 20 & 22 & 20 \\
\hline $6 \mathrm{~g}$ & {$\left[\mathrm{Cd}(\mathrm{HL})_{2}\right]$} & 30 & 40 & 12 \\
\hline Standar & (Carbendazim) & 24 & 26 & - \\
\hline Standar & (Streptomycin) & - & - & 40 \\
\hline
\end{tabular}

\section{ACKNOWLEDGEMENTS}

Authors are thankful to the Principal Deogiri College, Aurangabad (M.S.) for providing necessary laboratory facilities. One of the authors; SPB sincerely thanks to UGC for awarding SRF [Sr. No. 2121310320, Ref. No: 22/12/2013 (ii) EU-V].

\section{CONFLICT OF INTEREST}

The authors declare that there is no conflict of interests regarding the publication of this article.

\section{REFERENCES}

1. S. Naskar, S. Naskar, R.J. Butcher and S.K. Chattopadhyay, Inorg. Chim. Acta, 363, 404 (2010);

https://doi.org/10.1016/j.ica.2009.11.007.

2. M.V. Angelusiu, S.F. Barbuceanu, C. Draghici and G.L. Almajan, Eur. J. Med. Chem., 45, 2055 (2010); https://doi.org/10.1016/j.ejmech.2010.01.033.

3. Q. Wang, Z.Y. Yang, G.F. Qi and D.-D. Qin, Biometals, 22, 927 (2009); https://doi.org/10.1007/s10534-009-9245-0.

4. H.G. Aslan, S. Ozcan and N. Karacan, Inorg. Chem. Commun., 14, 1550 (2011); https://doi.org/10.1016/j.inoche.2011.05.024.

5. V.P. Singh, A. Katiyar and S. Singh, Biometals, 21, 491 (2008); https://doi.org/10.1007/s10534-008-9136-9.

6. S.N. Pandeya, D. Sriram, G. Nath and E. DeClercq, Eur. J. Pharm. Sci., 9, 25 (1999);

https://doi.org/10.1016/S0928-0987(99)00038-X.

7. S.A. Patil, M. Manjunath, U.V. Kamble and P.S. Badami, Der Pharma Chem., 3, 97 (2011).

8. E.W. Ainscough, A.M. Brodie, A.J. Dobbs, J.D. Ranford and J.M. Waters, Inorg. Chim. Acta, 267, 27 (1998); https://doi.org/10.1016/S0020-1693(97)05548-5.

9. A.A. Osowole, I. Ott and O.M. Ogunlana, Int. J. Inorg. Chem., Article 2012, ID 206417 (2012); https://doi.org/10.1155/2012/206417.

10. G. Marpadga, G.S. Rajender Reddy and M.C. Ganorkar, Transition Met. Chem., 21, 101 (1996); https://doi.org/10.1007/BF00136536.

11. S.M. Jadhav, A.S. Munde, S.G. Shankarwar, V.R. Patharkar, V.A. Shelke and T.K. Chondhekar, J. Korean Chem. Soc., 54, 515 (2010); https://doi.org/10.5012/jkcs.2010.54.5.515.

12. A. Ourari, W. Derafa and D. Aggoun, RSC Adv, 5, 82894 (2015); https://doi.org/10.1039/C5RA10819E. 
13. Y. Nakayama, H. Bando, Y. Sonobe and T. Fujita, J. Mol. Catal. Chem., 213, 141 (2004); https://doi.org/10.1016/j.molcata.2003.11.025.

14. H.H. Monfared, S. Sadighian, M.A. Kamyabi and P. Mayer, J. Mol. Catal. Chem., 304, 139 (2009);

https://doi.org/10.1016/j.molcata.2009.02.004.

15. K.G. Thomas and P.V. Kamat, J. Am. Chem. Soc., 122, 2655 (2000); https://doi.org/10.1021/ja9941835.

16. D.P. Singh, D.S. Raghuvanshi, K.N. Singh and V.P. Singh, J. Mol. Catal. A, 379, 21 (2013); https://doi.org/10.1016/j.molcata.2013.07.011.

17. S.S. Pawar, C.S. Patil, V.B. Tadke and R.P. Pawar, Int. J. Curr. Adv. Res., 7, 12934 (2018).

18. R.U. Ambhure, S.R. Mirgane, D.U. Thombal, R.B. Nawale, R.P. Marathe and R.P. Pawar, Modern Org. Chem. Res., 2, 11 (2017); https://doi.org/10.22606/mocr.2017.21003.
19. D.U. Thombal, S.R. Mirgane, R.U. Ambhure, R.P. Pawar and K.L. Ameta, Biochem. Biophys., 3, 7 (2017); https://doi.org/10.14355/bab.2017.03.002.

20. A.I. Vogel, Text Book of Practical Organic Chemistry, Longman: London, edn 5 (1989).

21. N. Chitrapriya, T. Sathiya Kamatchi, M. Zeller, H. Lee and K. Natarajan, Spectrochim. Acta A, 81, 128 (2011); https://doi.org/10.1016/j.saa.2011.05.069.

22. U. Kendur, G.H. Chimmalagi, S.M. Patil, K.B. Gudasi, C.S. Frampton, C.V. Mangannavar and I.S. Muchchandi, J. Mol. Struct., 1153, 299 (2018); https://doi.org/10.1016/j.molstruc.2017.10.022.

23. V. Kamat, D. Kokare, K. Naik, A. Kotian, S. Naveen, S.R. Dixit, N.K. Lokanath, S.D. Joshi and V.K. Revankar, Polyhedron, 127, 225 (2017); https://doi.org/10.1016/j.poly.2017.02.010. 